\title{
Pengaruh Motivasi Kerja, Gaya Kepemimpinan Dan Kompensasi Terhadap Kinerja Karyawan Pada Perusahaan Konstruksi PT. Pundikarya Sejahtera Bekasi
}

\author{
Setiyono \\ Sekolah Tinggi Teknik Malang \\ setyoothex@gmail.com
}

Diserahkan: 25 Juni 2016, Diterima: 2 Pebruari 2017

\begin{abstract}
This research takes object at PT. Pundikarya Sejahtera Bekasi City, aims to determine the influence of motivation, leadership style, compensation on employee performance at PT. Pundikarya Sejahtera Kota Bekasi and which variable is the most dominant effect on employee performance. Data were collected through questionnaires involving 52 employees as both population and sample. Data analysis using SPSS program with data analysis technique using multiple linier regression analysis. The results showed that motivation and compensation have a significant effect on employee performance, while leadership style has no significant effect on employee performance, and the compensation variable is the most dominant influence to employee performance.
\end{abstract}

Keywords: motivation, leadership style, compensation and employee performance

\begin{abstract}
Abstrak
Penelitian ini mengambil objek di PT. Pundikarya Sejahtera Kota Bekasi ini bertujuan untuk mengetahui pengaruh motivasi, gaya kepemimpinan, kompensasi terhadap kinerja karyawan pada kontraktor bangunan PT. Pundikarya Sejahtera Kota Bekasi serta variabel manakah yang paling dominan berpengaruh terhadap kinerja karyawan. Data dikumpulkan melalui kuesioner yang melibatkan 52 karyawan sebagai populasi sekaligus sampelnya. Analisis data menggunakan program SPSS dengan teknik analisa data menggunakan analisis regresi linier berganda. Hasil penelitian menunjukkan bahwa motivasi dan kompensasi berpengaruh signifikan terhadap kinerja karyawan, sedangkan gaya kepemimpinan tidak berpengaruh signifikan terhadap kinerja karyawan, dan variabel kompensasi adalah yang paling dominan berpengaruh terhadap kinerja karyawan.
\end{abstract}

Kata kunci: motivasi, gaya kepemimpinan, kompensasi dan kinerja karyawan

\section{A. PENDAHULUAN}

Perusahaan tidak mungkin terlepas dari tenaga kerja manusia, walaupun aktifitas perusahaan itu telah mempunyai modal yang cukup besar dan teknologi modern, sebab bagaimanapun majunya teknologi tanpa ditunjang oleh manusia sebagai sumber daya maka tujuan perusahaan tidak akan tercapai. Sehingga sumber daya manusia sangat penting untuk diberikan arahan dan bimbingan dari manajemen perusahaan pada umumnya dan manajemen sumber daya manusia pada khususnya.

Banyak faktor yang mempengaruhi kinerja karyawan antara lain faktor kepuasan kerja, faktor komunikasi, faktor pengalaman kerja, faktor kedisiplinan, faktor motivasi, faktor kepemimpinan, faktor kompetensi, faktor kompensasi dan faktor lingkungan kerja. Menurut observasi yang dilakukan peneliti, berbagai hal permasalahan tersebut ditemukan di lokasi penelitian yaitu PT. Pundi Karya Sejahtera. Sebagian karyawan memiliki motivasi kerja yang rendah, karyawan datang terlambat, karyawan pulang lebih cepat, masih adanya karyawan yang suka duduk santai pada jam kerja. Semangat untuk melakukan aktivitas masih rendah, adanya gaya kepemimpinan yang kurang tegas, tidak adanya sanksi yang tegas, keluhan karyawan tentang gaji yang pas-pasan, dan hal itu menunjukkan masih rendahnya kinerja karyawan terhadap perusahaan.

Dalam hal ini peneliti ingin mengangkat tiga faktor yaitu motivasi kerja, gaya kepemimpinan dan kompensasi. Pemilihan ini didasarkan pada kenyataan bahwa ketiga 
faktor tersebut paling sering muncul dalam teori yang membicarakan faktor-faktor yang berpengaruh terhadap kinerja karyawan.

Berdasarkan pada data tentang kinerja karyawan PT. Pundikarya Sejahtera yang terekap dalam Laporan Tahunan PT. Pundikarya Sejahtera dimana terjadi penurunan kinerja dari tahun 2013 ke tahun 2014. Tahun 2013 sebesar 9,65 dan tahun 2014 sebesar 9,35 (turun sebesar 0,30). Masing-masing penilaian dinilai kesesuaian antara perencanaan dan realisasinya.Realisasi yang semakin sesuai dengan perencanaan semakin tinggi nilainya.

Oleh karena itu peneliti tertarik untuk mengadakan penelitian tentang kinerja karyawan pada perusahaan konstruksi PT. Pundikarya Sejahtera dalam rangka menyusun tesis yang berjudul Pengaruh Motivasi Kerja, Gaya Kepemimpinan dan Kompensasi terhadap Kinerja Karyawan pada Perusahaan Konstruksi PT. Pundikarya Sejahtera Kota Bekasi.

\section{B. KAJIAN PUSTAKA Motivasi Kerja}

Motivasi ditinjau dari ilmu manajemen merupakan suatu fungsi atau alat yang erat kaitannya dengan manusia sebagai penggerak orang-orang agar mampu melakukan kegiatan-kegiatan organisasi. Bagi pimpinan organisasi kegiatan manajemen penting dalam meningkatkan kinerja organisasi.Kegiatan-kegiatan yang dilakukan oleh para bawahan dapat menunjang kearah pencapaian tujuan secara efektif dan efisien.Setiap pimpinan selalu berusaha melaksanakan motivasi kepada para bawahannya walaupun kenyataannya selalu mengalami hambatan, mengingat orang-orang mempunyai keinginan dan kebutuhan yang berbeda-beda.Ada banyak pendapat dari peneliti atau penulis tentang definisi motivasi, antara lain yang dikemukakan oleh Hasibuan (2010:143) yang menyatakan motivasi sebagai pemberian daya penggerak yang menciptakan kegairahan kerja seseorang agar mereka mau bekerjasama, bekerja efektif dan terintegrasi dengan segala daya upayanya untuk mencapai kepuasan. Motivasi akan memberikan arti besar kecilnya usaha seseorang, berusaha atau bekerja giat untuk mencapai kebutuhannya. Sebaliknya seseorang dengan motivasi yang rendah tidak akan pernah mencapai hasil melebihi kekuatan motivasinya.

\section{Gaya Kepemimpinan}

Kepemimpinan atau leadership merupakan ilmu terapan dari ilmu-ilmu sosial, sebab prinsip-prinsip dan rumusannya diharapkan dapat mendatangkan manfaat bagi kesejahteraan manusia. Ada banyak pengertian yang dikemukakan oleh para pakar menurut sudut pandang masing-masing, definisi-definisi tersebut menunjukkan ada beberapa kesamaan. Wahjosumidjo (1987:11) menyatakan bahwa kepemimpinan pada hakikatnya adalah suatu yang melekat pada diri seorang pemimpin yang berupa sifatsifat tertentu seperti: kepribadian (personality), kemampuan (ability) dan kesanggupan (capability). Kepemimpinan juga sebagai rangkaian kegiatan (activity) pemimpin yang tidak dapat dipisahkan dengan kedudukan (posisi) serta gaya atau perilaku pemimpin itu sendiri. Kepemimpinan adalah proses antar hubungan atau interaksi antara pemimpin, pengikut dan situasi.

Sutarto (1998:25) menyatakan bahwa kepemimpinan adalah rangkaian kegiatan penataan berupa kemampuan mempengaruhi perilakau orang lain dalam situasi tertentu agar bersedia bekerja sama untuk mencapai tujuan yang telah ditetapkan. 


\section{Kompensasi}

Kompensasi adalah masalah yang sensitif karena menjadi pendorong seseorang untuk bekerja juga berpengaruh terhadap moral dan kedisiplinan tenaga kerja. Oleh karena itu setiap perusahaan/ organisasi manapun seharusnya dapat memberikan kompensasi yang seimbang dengan beban kerja yang dipikul tenaga kerja. Ada banyak definisi yang dikemukakan oleh peneliti atau penulis, beberapa diantaranya adalah Sastrohadiwirjo (2003:181) yang mendefinisikan kompensasi sebagai imbalan jasa/ balas jasa yang diberikan oleh perusahaan kepada tenaga kerja karena tenaga kerja tersebut telah memberikan sumbangan tenaga dan pikiran demi kemajuan perusahaan guna mencapai tujuan yang telah ditetapkan.

\section{Kinerja}

Kinerja adalah catatan tentang hasil yang diperoleh dari fungsi-fungsi pekerjaan tertentu atau kegiatan selama kurun waktu tertentu (Bernardin \& Russel, 1993). Definisi ini juga relevan dengan definisi yang diformulasikan oleh peneliti atau penulis lain misalnya Hasibuan (2010:105) yang menyatakan bahwa kinerja karyawan didefinisikan sebagai suatu hasil yang dicapai oleh seseorang dalam melaksanakan tugas-tugas yang dibebankan kepadanya yang didasarkan atas kecakapan, pengalaman dan kesungguahan serta waktu.

\section{Kerangka Konseptual Penelitian}

Motivasi Kerja $\left(\mathrm{X}_{1}\right)$

Kebutuhan Fisik $\left(\mathrm{X}_{1.1}\right)$

Kebutuhan Rasa Aman dan

Keselamatan $\left(\mathrm{X}_{1.2}\right)$

Kebutuhan Sosial $\left(\mathrm{X}_{1.3}\right)$

Kebutuhan akan Penghargaan $\left(\mathrm{X}_{1.4}\right)$

Kebutuhan Perwujudan Diri $\left(\mathrm{X}_{1.5}\right)$

(Maslow, 2003)

Gaya Kepemimpinan $\left(\mathrm{X}_{2}\right)$

Gaya Eksekutif $\left(\mathrm{X}_{2.1}\right)$

Gaya Otokrat Bijak $\left(\mathrm{X}_{2.2}\right)$

Gaya Pembina $\left(\mathrm{X}_{2.3}\right)$

Gaya Birokrat $\left(\mathrm{X}_{2.4}\right)$

(Reddin, 1967)

Kompensasi $\left(\mathrm{X}_{3}\right)$

Kompensasi Langsung $\left(\mathrm{X}_{3.1}\right)$

Kompensasi Tidak langsung $\left(\mathrm{X}_{3.2}\right)$

(Stone, 2005)

Kinerja Karyawan (Y)

Kualitas $\left(\mathrm{Y}_{1}\right)$

Kuantitas $\left(\mathrm{Y}_{2}\right)$

Ketepatan Waktu $\left(\mathrm{Y}_{3}\right)$

Efektivitas Biaya $\left(\mathrm{Y}_{4}\right)$

Kemampuan Bekerja tanpa

Pengawasan $\left(\mathrm{Y}_{5}\right)$

Dampak Interpersonal $\left(\mathrm{Y}_{6}\right)$

(Bernardin dan Russel, 1993)

Gambar 1: Kerangka Konseptual Penelitian

\section{Hipotesis}

Berdasarkan kajian teori yang dikemukakan maka hipotesis dalam penelitian ini adalah: 
H1 : Motivasi kerja, gaya kepemimpinan dan kompensasi secara bersama berpengaruh signifikan terhadap kinerja karyawan pada perusahaan konstruksi PT. Pundikarya Sejahtera Kota Bekasi.

$\mathrm{H} 2$ : Kompensasi berpengaruh dominan terhadap kinerja karyawan pada perusahaan konstruksi PT. Pundikarya Sejahtera Kota Bekasi.

\section{METODE PENELITIAN}

Rancangan penelitian ini menggunakan rancangan penelitian atau desain penelitian kausalitas yaitu desain penelitian yang disusun untuk meneliti kemungkinan adanya hubungan sebab akibat antarvariabel (Sanusi, 2014:14). Ruang lingkup penelitian ini dititikberatkan pada variabel kinerja, terutama yang menyangkut pengaruh antara variable independen gaya kepemimpian, kompensasi dan motivasi kerja terhadap variabel dependen kinerja karyawan pada perusahaan konstruksi PT. Pundikarya Sejahtera Kota Bekasi.

Penelitian ini menggunakan data primer, yakni data yang diperoleh melalui kuisioner yang berisi respon tertulis dari responden berkaitan dengan butir-butir pertanyaan atau pernyataan yang dielaborasi dari masing-masing indikator pada setiap variabel.

\section{HASIL DAN PEMBAHASAN}

PT. Pundi Karya Sejahtera merupakan perusahaan kontraktor bangunan yang berkantor di Perumahan Pesona Anggrek Blok B10/10 RT 06 RW 27 Kelurahan Harapan Jaya Kecamatan Bekasi Utara Kota Bekasi, Jawa Barat.PT. Pundi Karya Sejahtera bergerak di bidang konstruksi bangunan yang meliputi bangunan gedung dan instalasinya, bangunan air, dan bangunan fungsional lainnya.Perusahaan ini didirikan pada tahun 2011 dan merupakan anggota dari Asosiasi Gabungan Pekerja Konstruksi Indonesai (Gapeksindo) yang merupakan regulator perusahaan konstruksi di Indonesia.PT. Pundi Karya Sejahtera bertekad untuk menjadi sebuah perusahaan jasa layanan dengan kualifikasi dan kompetensi nasional serta berorientasi bisnis secara profesional. Dan berupaya untuk menjadi sebuah perusahaan jasa yang terdepan dalam bidangnya dengan selalu memberikan solusi yang inovatif sehingga setiap mitra dari PT. Pundi Karya Sejahtera akan selalu puas dengan pelayanan yang diberikan.

\section{Uji Validitas}

Uji validitas dilakukan untuk mengetahui derajat ketepatan dari instrumen yang digunakan dalam pengumpulan data. Suatu instrumen dikatakan valid apabila mampu mengukur apa yang diinginkan dan dapat mengungkap data dari variabel yang diteliti dengan lengkap. Tinggi rendahnya validitas menunjukkan sejauh mana data yang terkumpul tidak menyimpang dari gambaran tentang variabel yang dimaksud.

Uji validitas butir indikator dapat dilakukan dengan menggunakan software SPSS. Proses ini menggunakan Uji Korelasi Pearson Product Moment. Dalam uji ini setiap item akan diuji relasinya dengan skor total variabel yang dimaksud yaitu masing-masing item yang ada di dalam variabel $\mathrm{X}$ dan $\mathrm{Y}$ diuji relasinya dengan skor total variabel tersebut. Valid atau tidaknya suatu indikator instrumen dapat diketahui dengan membandingkan indeks korelasi Pearson Product Moment dengan level signifikansi 95\%. Peneliti menggunakan sampel uji kuesioner sebanyak 52 orang responden dengan probabilitas $\alpha=5 \%$, dari sini didapat nilai df $=n-2, \mathrm{df}=52-2=50$. Kita lihat tabel $\mathrm{r}$ product moment pada probabilitas $\alpha=5 \%$ didapatkan angka rtabel $=0.2732$. 
Tabel 1: Hasil Uji Validitas

\begin{tabular}{|c|c|c|c|c|c|}
\hline Variabel & item & $\begin{array}{c}\text { Koefisien } \\
\text { korelasi }\end{array}$ & $\mathrm{r}$ tabel & Sig. & Keterangan \\
\hline \multirow{10}{*}{$\begin{array}{l}\text { Motivasi kerja } \\
\qquad\left(\mathrm{X}_{1}\right)\end{array}$} & 1 & 0.574 & 0.2732 & 0.000 & Valid \\
\hline & 2 & 0.826 & 0.2732 & 0.000 & Valid \\
\hline & 3 & 0.457 & 0.2732 & 0.001 & Valid \\
\hline & 4 & 0.393 & 0.2732 & 0.004 & Valid \\
\hline & 5 & 0.820 & 0.2732 & 0.000 & Valid \\
\hline & 6 & 0.581 & 0.2732 & 0.000 & Valid \\
\hline & 7 & 0.460 & 0.2732 & 0.001 & Valid \\
\hline & 8 & 0.302 & 0.2732 & 0.030 & Valid \\
\hline & 9 & 0.649 & 0.2732 & 0.000 & Valid \\
\hline & 10 & 0.868 & 0.2732 & 0.000 & Valid \\
\hline Gaya & 11 & 0.646 & 0.2732 & 0.000 & Valid \\
\hline \multirow{7}{*}{$\begin{array}{l}\text { kepemimpinan } \\
\left(\mathrm{X}_{2}\right)\end{array}$} & 12 & 0.706 & 0.2732 & 0.000 & Valid \\
\hline & 13 & 0.504 & 0.2732 & 0.000 & Valid \\
\hline & 14 & 0.498 & 0.2732 & 0.000 & Valid \\
\hline & 15 & 0.300 & 0.2732 & 0.031 & Valid \\
\hline & 16 & 0.559 & 0.2732 & 0.000 & Valid \\
\hline & 17 & 0.758 & 0.2732 & 0.000 & Valid \\
\hline & 18 & 0.475 & 0.2732 & 0.000 & Valid \\
\hline \multirow[t]{7}{*}{ Kompensasi $\left(\mathrm{X}_{3}\right)$} & 19 & 0.513 & 0.2732 & 0.000 & Valid \\
\hline & 20 & 0.412 & 0.2732 & 0.002 & Valid \\
\hline & 21 & 0.794 & 0.2732 & 0.000 & Valid \\
\hline & 22 & 0.485 & 0.2732 & 0.000 & Valid \\
\hline & 23 & 0.567 & 0.2732 & 0.000 & Valid \\
\hline & 24 & 0.347 & 0.2732 & 0.012 & Valid \\
\hline & 25 & 0.792 & 0.2732 & 0.000 & Valid \\
\hline \multirow[t]{12}{*}{ Kinerja (Y) } & 26 & 0.322 & 0.2732 & 0.020 & Valid \\
\hline & 27 & 0.459 & 0.2732 & 0.001 & Valid \\
\hline & 28 & 0.393 & 0.2732 & 0.004 & Valid \\
\hline & 29 & 0.544 & 0.2732 & 0.000 & Valid \\
\hline & 30 & 0.563 & 0.2732 & 0.000 & Valid \\
\hline & 31 & 0.586 & 0.2732 & 0.000 & Valid \\
\hline & 32 & 0.442 & 0.2732 & 0.001 & Valid \\
\hline & 33 & 0.281 & 0.2732 & 0.044 & Valid \\
\hline & 34 & 0.544 & 0.2732 & 0.000 & Valid \\
\hline & 35 & $0 . .419$ & 0.2732 & 0.002 & Valid \\
\hline & 36 & 0.459 & 0.2732 & 0.001 & Valid \\
\hline & 37 & 0.563 & 0.2732 & 0.000 & Valid \\
\hline
\end{tabular}

Sumber: Data primer diolah, 2015

Dari pengolahan data dapat dilihat 37 indikator pernyataan yang diuji, semua item pernyataan mempunyai nilai koefisien korelasi positif dan lebih besar dari rtabel, serta probabilitasnya lebih kecil dari $\alpha=5 \%$ yang artinya ada hubungan yang signifikan antara ekor masing-masing item pernyataan dengan skor total. Korelasi yang signifikan menunjukkan bahwa indikator memang benar-benar dapat digunakan untuk mengukur item pernyataan yang akan diukur, dengan kata lain instrumen yang digunakan valid sehingga dapat dipakai dalam penelitian.

\section{Uji Realiabilitas}

Uji reliabilitas dimaksudkan untuk mengetahui adanya korelasi instrumen dalam penggunaannya atau dengan kata lain alat ukur tersebut mempunyai hasil yang konsisten apabila digunakan berkali-kali pada waktu yang berbeda. Pengujian reliabilitas dalam penelitian ini menggunakan metode Alpha Cronbach yang bertujuan untuk menguji instrumen yang digunakan. Dari hasil pengujian reliabilitas dinyatakan 
bahwa semua variabel yang diteliti dinyatakan reliabel karena nilainya lebih besar dari 0,6 pada derajat kepercayaan 5\%. Diketahui nilai rtabel pada signifikansi 5\% dengan jumlah data $\mathrm{n}=52$ didapat $\mathrm{r}$ sebesar 0,2732 dan nilai Alpha Cronbach $>$ rtabel maka dapat disimpulkan bahwa butir-butir instrumen penelitian tersebut reliabel. Dengan demikian data yang digunakan adalah valid dan memeiliki reabilitas yang baik.

\section{Analisis Deskriptif Variabel}

Analisis deskriptif dilakukan melalui penjelasan dalam bentuk tabel-tabel distribusi frekuensi yang selanjutnya diberikan analisis baik secara teoritis maupun secara empiris. Variabel motivasi kerja yang mempunyai nilai rata-rata skor tertinggi adalah pemberian uang makan dan keselamatan tempat kerja sebesar 4,1346. Hal ini menunjukkan bahwa rata-rata karyawan PT. Pundi Karya Sejahtera menyatakan setuju bahwa uang makan yang diberikan perusahaan sudah memacu semangat kerja dan keselamatan di tempat kerja sudah memadai.

Variabel gaya kepemimpianan yang mempunyai nilai rata-rata skor tertinggi adalah memperhatikan pentingnya biaya dan memelihara komunikasi yang baik sebesar 4,000. Hal ini menunjukkan bahwa rata-rata karyawan PT. Pundi Karya Sejahtera setuju dengan pemimpin yang berprakarsa dan berperan dalam memperhatikan pentingnya biaya dan memelihara komunikasi yang baik.

Variabel kompensasi yang mempunyai nilai rata-rata skor tertinggi adalah tunjangan keluarga sebesar 4,1731. Hal ini menunjukkan bahwa rata-rata karyawan PT. Pundi Karya Sejahtera setuju bahwa pemberian tunjangan keluarga oleh perusahaan sudah sesuai dengan beban tanggungjawab karyawan.

Variabel kinerja karyawan yang mempunyai nilai rata-rata skor tertinggi adalah indikator ketepatan kerja sebesar 4,1932. Hal ini menunjukkan bahwa rata-rata karyawan PT. Pundi Karya Sejahtera setuju dalam melaksanakan pekerjaan karyawan tidak pernah melakukan kesalahan yang fatal hingga harus mengulang pekerjaan tersebut dari awal.

\section{Analisis Regresi Linear Berganda}

Analisis regresi linear berganda adalah hubungan secara linear antara dua atau lebih variabel independen dengan variabel dependen.Analisis ini untuk mengetahui arah hubungan antara variabel independen dengan variabel dependen apakah masing-masing variabel independen berhubungan positif atau negatif dan untuk memprediksi nilai dari variabel dependen apabila nilai variabel independen mengalami kenaikan atau penurunan. Data yang digunakan biasanya berskala interval atau rasio.

Pengaruh variabel motivasi, gaya kepemimpinan dan kompensasi terhadap kinerja karyawan PT. Pundikarya Sejahtera dengan persamaan sbb:

$$
\mathrm{Y}=11,357+0,043 \mathrm{X} 1+0,007 \mathrm{X} 2+1,275 \mathrm{X} 3+\varepsilon
$$

Keterangan:

$$
\begin{array}{ll}
\mathrm{a} & =\text { konstanta } \\
\mathrm{Y} & =\text { kinerja karyawan } \\
\mathrm{X}_{1}, \mathrm{X}_{2}, \mathrm{X}_{3} & =\text { motivasi kerja, gaya kepemimpinan, kompensasi }(\%) \\
\mathrm{b}_{1}, \mathrm{~b}_{2}, \mathrm{~b}_{3} & =\text { koefisien regresi } \\
\varepsilon & =\text { error }
\end{array}
$$

Koefisien regresi variabel kinerja karyawan sebesar 0.043 artinya jika variabel independen lain nilainya tetap maka motivasi kerja mengalami kenaikan $1 \%$ maka nilai kinerja karyawan akan mengalami peningkatan sebesar 0.043 . Koefisien bernilai positif artinya terjadi hubungan positif antara motivasi kerja dengan kinerja karyawan, semakin naik motivasi kerja maka semakin meningkat kinerja karyawan. 
Koefisien regresi variabel gaya kepemimpinan sebesar 0.007 artinya jika variabel independen lain nilainya tetap maka gaya kepemimpinan mengalami kenaikan $1 \%$ maka nilai kinerja karyawan akan mengalami peningkatan sebesar 0.007 . Koefisien bernilai positif artinya terjadi hubungan positif antara gaya kepemimpinan dengan kinerja karyawan, semakin naik gaya kepemimpinan maka semakin tinggi kinerja karyawan.

Koefisien regresi variabel kompensasi sebesar 1.275 artinya jika variabel independen lain nilainya tetap maka kompensasi mengalami kenaikan 1\% maka nilai kinerja karyawan akan mengalami peningkatan sebesar 1.275. Koefisien bernilai positif artinya terjadi hubungan positif antara kompensasi dengan kinerja karyawan, semakin naik kompensasi maka semakin meningkat kinerja karyawan.

Uji Determinasi (R2).

Analisis koefisien determinasai (R2) digunakan untuk mengetahui seberapa besar prosentase sumbangan pengaruh variabel independen secara serentak terhadap variabel dependen.Koefisien determinasi dapat dilihat pada tabel Model Summary (hasil output olah data) R2 (Adjusted R Square). Nilai R2 adalah sumbangan pengaruh variabel independen terhadap variabel dependen sedangkan sisanya dipengaruhi oleh faktor lain yang tidak diteliti.Nilai R2 (Adjusted R Square) adalah 0.797, jadi sumbangan pengaruh variabel independen sebesar $79.7 \%$ terhadap variabel dependen sedangkan sisanya sebesar $20.3 \%$ dipengaruhi oleh faktor lain yang tidak diteliti.

\section{Uji Hipetesis 1 (satu) dengan uji - F}

Selanjutnya dilakukan uji model dengan menentukan besarnya Fhitung dengan menggunakan Uji F yang dimaksudkan untuk mengetahui pengaruh variabel bebas (X) secara simultan terhadap variabel terikat (Y), dengan cara membandingkan antara Fhitung dengan Ftabel, jika telah memenuhi persyaratan yaitu Fhitung > Ftabel maka hipotesis dapat diterima. Kemudian melihat tingkat signifikansi pada $\alpha=0$.05. Diketahui nilai Fhitung $=67.940$ dan Ftabel pada df $1=3$ dan df $2=48$ diperoleh Ftabel $=2.80$. Nilai Fhitung lebih besar dari Ftabel yaitu $67.940>2.80$ pada tingkat signifikansi $\alpha=$ $5 \%$ yang berarti terdapat pengaruh yang signifikan antara variabel Motivasi Kerja, Gaya Kepemimpinan dan Kompensasi secara simultan berpengaruh terhadap Kinerja Karyawan pada Perusahaan Konstruksi PT. Pundi Karya Sejahtera Kota Bekasi.

Dengan demikian hipotesis 1 (satu) yang menyatakan bahwa variabel Motivasi Kerja, Gaya Kepemimpinan dan Kompensasi secara simultan berpengaruh terhadap Kinerja Karyawan pada Perusahaan Konstruksi PT. Pundi Karya Sejahtera Kota Bekasi dinyatakan telah teruji.

\section{Uji Hipotesis 2 (Uji t)}

Uji t dimaksukan untuk mengetahui pengaruh variabel bebas $(\mathrm{X})$ secara parsial terhadap variabel terikat $(\mathrm{Y})$, dengan cara membandingkan antara t-hitung dengan $\mathrm{t}-$ tabel, jika telah memenuhi persyaratan yaitu t-hitung $>\mathrm{t}$-tabel maka hipotesis dapat diterima. Kemudian melihat tingkat signifikansi pada $\alpha<0.05$. Rumus untuk mencari nilai $\mathrm{t}$-tabel $=$ tingkat kepercayaan dibagi 2 (dua); jumlah responden dikurangi jumlah variabel bebas dikurangi 1 (satu) atau jika ditulis dalam bentuk rumus sebagai berikut:

$$
\mathrm{t} \text {-tabel }=\alpha / 2 ; \mathrm{n}-\mathrm{k}-1
$$

$$
\mathrm{t} \text {-tabel }=0.05 / 2 ; 52-3-1
$$

$\mathrm{t}$-tabel $=0.025 ; 48$

Selanjutnya, dicari pada distribusi nilai t-tabel maka ditemukan nilai t-tabel sebesar 2.01063.

Selanjutnya untuk menguji hipotesis 2 (dua) bahwa variabel kompensasi adalah variabel yang berpengaruh dominan terhadap kinerja karyawan pada perusahaan 
konstruksi PT. Pundi Karya Sejahtera dari koefisien beta $(\beta)$ terstandarisasi yang terbesar.

Berdasarkan analisis masing-masing variabel menunjukkan koefisien $\beta$ yang terstandarisasi dengan hasil koefisien $\beta 3$ kompensasi $=0.897$ terbesar diikuti oleh koefisien $\beta 1$ motivasi kerja $=0.058$ dan yang terakhir koefisien $\beta 2$ gaya kepemimpinan $=0.006$. Dengan demikian variabel yang berpengaruh dominan dan signifikan terhadap kinerja karyawan adalah kompensasi artinya untuk meningkatkan dan membentuk kinerja karyawan pada perusahaan konstruksi PT. Pundi Karya Sejahtera yang paling signifikan adalah kompensasi.

Dengan demikian hipotesis 2 (dua) yang menyatakan bahwa variabel kompensasi adalah variabel yang berpengaruh dominan terhadap kinerja karyawan pada perusahaan konstruksi PT. Pundi Karya Sejahtera dinyatakan telah teruji.

Deskripsi masing-masing variabel yang diukur dari pernyataan responden terhadap kuesioner sebagai berikut:

\section{Pengaruh Motivasi Kerja terhadap Kinerja Karyawan}

Hasibuan (2010:143) menyatakan bahwa motivasi sebagai pemberian daya penggerak yang menciptakan kegairahan kerja seseorang agar mereka mau bekerjasama, bekerja efektif dan terintegrasi dengan segala daya upayanya untuk mencapai kepuasan.

Berdasarkan hasil analisis deskripsi dapat diketahui bahwa motivasi kerja yang diukur dengan indikator pemberian uang makan, pemberian bonus, dana pensiun, keselamatan tempat kerja, kebebasan koordinasi, kebutuhan sosial, kebutuhan akan penghargaan diri, pengakuan akan prestasi, kemampuan dan keterampilan potensial optimal telah menunjukkan akan meningkatkan kinerja karyawan PT.Pundi Karya Sejahtera. Hal ini dapat diketahui dari pernyataan sebagian besar responden yang menjawab setuju dan sangat setuju bahwa uang makan yang diberikan perusahaan telah memacu semangat kerja dan keselamatan di tempat kerja telah memadai.

Dari hasil analisis regresi dapat diketahui bahwa variabel motivasi kerja secara statistik mempunyai pengaruh yang signifikan terhadap kinerja karyawan PT. Pundikarya Sejahtera yaitu peningkatan terhadap motivasi kerja akan diikuti juga oleh peningkatan kinerja karyawan, semakin naik motivasi kerja maka semakin meningkat kinerja karyawan PT. Pundi Karya Sejahtera.

\section{Pengaruh Gaya Kepemimpinan terhadap Kinerja Karyawan}

Sutarto (1998:25) menyatakan bahwa kepemimpinan adalah rangkaian kegiatan penataan berupa kemampuan mempengaruhi perilakau orang lain dalam situasi tertentu agar bersedia bekerja sama untuk mencapai tujuan yang telah ditetapkan.

Berdasarkan hasil analisis deskripsi dapat diketahui bahwa gaya kepemimpinan yang diukur dengan indikator penggunaan partisipasi secara tepat, sebagai motivator yang baik, berprakarsa dan energik, memperhatikan pentingnya biaya, memelihara komunikasi yang baik, memberi dukungan dan kerjasama yang baik, mentaati peraturan-peraturan yang ada, memelihara sistem kerja telah menunjukkan akan meningkatkan kinerja karyawan PT. Pundi Karya Sejahtera. Hal ini dapat diketahui dari pernyataan sebagian besar responden yang menjawab setuju dan sangat setuju bahwa pemimpin berprakarsa dan berperan dalam memperhatikan pentingnya biaya dan memelihara komunikasi yang baik.

Dari hasil analisis regresi dapat diketahui bahwa variabel gaya kepemimpinan secara parsial tidak berpengaruh signifikan terhadap kinerja karyawan PT. Pundikarya Sejahtera. Hal ini bermakna bahwa jika gaya kepemimpinan ditingkatkan tidak akan berpengaruh pada kinerja karyawan karena PT. Pundikarya Sejahtera merupakan 
perusahaan swasta yang mengutamakan peningkatan profit setiap tahunnya. Implementasi gaya kepemimpinan pada PT. Pundikarya Sejahtera selama ini yaitu segala keputusan dan kebijakan diambil secara penuh oleh pimpinan, segala pembagian tugas dan tanggungjawab dipegang oleh pemimpin tersebut dan para bawahan hanya melaksanakan tugas yang telah diberikan.

\section{Pengaruh Kompensasi terhadap Kinerja Karyawan}

Sastrohadiwirjo (2003:181) mendefinisikan kompensasi sebagai imbalan jasa/ balas jasa yang diberikan oleh perusahaan kepada tenaga kerja karena tenaga kerja tersebut telah memberikan sumbangan tenaga dan pikiran demi kemajuan perusahaan guna mencapai tujuan yang telah ditetapkan.

Berdasarkan hasil analisis deskripsi dapat diketahui bahwa kompensasi yang diukur dengan indikator gaji, uang makan, uang lembur, asuransi, fasilitas kantor, tunjangan keluarga, tunjangan jabatan telah menunjukkan akan meningkatkan kinerja karyawan PT. Pundi Karya Sejahtera. Hal ini dapat diketahui dari pernyataan sebagian besar responden yang menjawab setuju dan sangat setuju bahwa dalam pemberian tunjangan keluarga oleh perusahaan sudah sesuai.

Dari hasil analisis regresi dapat diketahui bahwa variabel kompensasi secara statistik mempunyai pengaruh yang signifikan terhadap kinerja karyawan PT. Pundikarya Sejahtera yaitu peningkatan terhadap kompensasi akan diikuti juga oleh peningkatan kinerja karyawan, semakin naik kompensasi maka semakin meningkat kinerja karyawan PT. Pundi Karya Sejahtera.

Berdasarkan hasil analisis regresi linear berganda menunjukkan bahwa variabel motivasi kerja dan kompensasi secara simultan berpengaruh terhadap kinerja karyawan pada Perusahaan Konstruksi PT. Pundi Karya Sejahtera Kota Bekasi.Dan diketahui bahwa di antara ketiga variabel bebas yang diteliti ternyata benar bahwa variabel Kompensasi yang berpengaruh paling besar terhadap kinerja karyawan PT. Pundi Karya Sejahtera. Hasil penelitian ini mendukung penelitian yang dilakukan oleh Dzulkifli (2013) yang menyatakan bahwa gaya kepemimpinan, motivasi, disiplin kerja, kompensasi dan budaya organisasi memiliki pengaruh signifikan terhadap kinerja pegawai dan variabel kompensasi merupakan variabel yang berpengaruh dominan terhadap kinerja pegawai. Selfianti (2013) menyatakan bahwa gaya kepemimpinan, motivasi, disiplin kerja dan kompensasi berpengaruh signifikan terhadap kinerja pegawai pada bidang pendapatan Kota Tanjungpinang serta Riyadi (2011) yang menyatakan bahwa kompensasi finansial dan gaya kepemimpinan secara signifikan mempengaruhi motivasi kerja maupun kinerja karyawan dan motivasi kerja secara signifikan mempengaruhi kinerja karyawan pada perusahaan manufaktur di Jawa Timur.

Pengaruh yang signifikan antara kompensasi terhadap kinerja didukung dengan fakta yang ada di lokasi penelitian. Besar atau kecilnya kompensasi seorang karyawan sangat mempengaruhi dalam melaksanakan tugas-tugasnya dengan lebih baik dan akan mempengaruhi kinerja. Terkait dengan beragam latar belakang pendidikan yang berbeda-beda pada perusahaan ini, pemberian kompensasi yang sesuai kepada karyawan sangat diperlukan untuk sinkronisasi pelaksanaan pekerjaan baik itu pekerjaan dengan lingkup yang besar atau pekerjaan dengan lingkup yang lebih kecil.

\section{E. PENUTUP}

Dari analisis dan pembahasan yang berkaitan dengan pengaruh motivasi kerja, gaya kepemimpinan dan kompensasi terhadap kinerja karyawan pada perusahaan konstruksi PT. Pundi Karya Sejahtera dapat disimpulkan bahwa variabel motivasi kerja, 
gaya kepemimpinan, kompensasi dan kinerja karyawan menunjukkan nilai rata-rata yang baik dimana sebagian besar responden menjawab item-item pertanyaan dengan jawaban setuju. Hal ini menunjukkan bahwa motivasi kerja, gaya kepemimpinan, kompensasi dan kinerja karyawan dalam penelitian ini ditanggapi positif oleh responden dalam hal ini karyawan PT. Pundi Karya Sejahtera.

Hasil dari pengujian hipotesis pertama diketahui bahwa motivasi kerja dan kompensasi berpengaruh signifikan terhadap kinerja karyawan PT. Pundi Karya Sejahtera sedangkan gaya kepemimpinan tidak berpengaruh signifikan terhadap kinerja karyawan PT. Pundi Karya Sejahtera. Motivasi kerja dan kompensasi yang diberikan perusahaan tempat bekerja memiliki pengaruh yang erat terhadap kinerja karyawan PT. Pundi Karya Sejahtera. Sedangkan asil pengujian hipotesis kedua diketahui bahwa kompensasi berpengaruh dominan terhadap kinerja karyawan PT. Pundi Karya Sejahtera, hal ini terlihat dari pemberian gaji yang telah dapat digunakan untuk kebutuhan hidup secara layak, uang makan yang diberikan telah sesuai dengan jumlah hari dalam bekerja begitu juga dengan uang lembur yang diterima telah sesuai dengan beban lembur. Pemberian asuransi kesehatan oleh perusahaan akan membantu dalam masalah pembiayaan kesehatan karyawan, fasilitas kantor yang ada juga telah sesuai dengan kebutuhan dan kenyamanan dalam bekerja. Pemberian tunjangan keluarga telah sesuai dengan beban pekerjaan dan tunjangan jabatan yang diberikan juga telah sesuai dengan tanggungjawab karyawan.

Dari simpulan tersebut, maka disarankan kepada PT. Pundi Karya Sejahtera agar memberikan ruang kepada karyawan agar bisa menyampaikan pendapat kepada pimpinan dan manajemen guna mendukung pelaksanaan tugas karyawan, menjaga koordinasi dan komunikasi antar pegawai dan pimpinan serta mempertahankan dan lebih memperhatikan lagi pemberian kompensasi baik secara langsung maupun tidak langsung kepada karyawan hendaknya dapat terpenuhi.

Untuk Peneliti selanjutnya disarankan agar peneliti dapat menambah variabel berpengaruh lain sehingga dapat diketahui faktor yang paling berpengaruh terhadap kinerja karyawan dan perlu dilakukan penelitian ulang untuk mengetahui kinerja karyawan setelah memperbaiki motivasi kerja dan kompensasi di lokasi penelitian.

\section{DAFTAR PUSTAKA}

Antonius Tanesi, 2014, Pengaruh Motivasi, Komunikasi Interpersonal dan Penghargaan terhadap Kinerja Pegawai pada UPT-PK Singosari, Universitas Merdeka Malang, Malang.

Anwar Saifuddin, 2000, Reliabilitas dan Validitas,edisi Ketiga,cetakan Pertama,Pustaka Pelajar, Yogyakarta.

Arikunto S, 2007,Manajemen Penelitian,PT. Rineka Cipta, Jakarta.

Bernardin H. John \& Russel E.A, 1993,Human Resources Management An Experiental Approach International Editions,Mac Graw Hill Book Co, Singapore.

Dzulkifli, 2013, Pengaruh Gaya Kepemimpinan, Motivasi, Disiplin Kerja, Kompensasi dan Budaya Organisasi terhadap Kinerja Pegawai pada Direktorat Budidaya dan Pascapanen Florikultura Pasar Minggu Jakarta Selatan, Universitas Diponegoro, Semarang.

Gujarati D, 2003, Basics Econometric, fourth edition, McGraw-Hill, Singapore.

Handoko T. Hani, 2001,Manajemen Personalia dan Sumber Daya Manusia, edisi Kedua,BPFE, Yogyakarta. 
Hasibuan Malayu S.P, 2010,Organisasi dan Motivasi Dasar Peningkatan Produktivitas,cetakan Ketujuh, PT. Bumi Aksara, Jakarta.

Hermalia, 2014, Pengaruh Kepemimpinan, Kemampuan dan Motivasi terhadap Kinerja Petugas Pemungut PBB pada Kantor Kecamatan Kanigaran Kota Probolinggo, Universitas Merdeka Malang, Malang.

Mangkunegara Anwar Prabu, 2005, Manajemen Sumber Daya Manusia Perusahaan,cetakan Keenam,PT. Remaja Rosdakarya, Bandung.

Martoyo Susilo, 2000, Manajemen Sumber Daya Manusia, edisi Keempat, BPFE, Yogyakarta.

Maslow Abraham, 2003, Motivasi dan Kepribadian, Midas Surya Gravindo, Jakarta.

Menteri Penertiban Aparatur Negara, 2001,Manajemen Sumber Daya Manusia,PT. Salemba Emban Patria, Jakarta.

Moekijat, 1992, Dasar-dasar Administrasi dan Manajemen Perusahaan, Mandar Maju, Bandung.

Nawawi H, 2005,Metode Penelitian Bidang Sosial,Gajah Mada University Press, Yogyakarta.

Reddin William J, 1967, The 3-D Management Style Theory : A Typology Based On Task and Relationship Orientations, Training and Development Journal, April 817

Riyadi, 2011, Pengaruh Kompensasi Finansial, Gaya Kepemimpinan dan Motivasi Kerja terhadap Kinerja Karyawan pada Perusahaan Manufaktur di Jawa Timur, Universitas Diponegoro, Semarang.

Robbins Stephen P, 2001,Perilaku Organisasi Konsep, Kontroversi, Aplikasi,edisi Bahasa Indonesia,PT. Prenhallindo, Jakarta.

Robbins Stephen P. dan Timothy A. Judge, 2008,Perilaku Organisasi Organizational Behavior,Salemba Empat, Jakarta.

Sanusi Anwar, 2014,Metodologi Penelitian Bisnis,cetakan Keempat, Salemba Empat, Jakarta.

Sastrohadiwiryo Siswanto, 2003, Manajemen Tenaga Kerja Indonesia Pendekatan Administratif dan Operasional, cetakan Pertama, PT. Bumi Aksara, Jakarta.

Saydam Gouzali, 2000, Manajemen Sumber Daya Manusia, Jilid 2, Gunung Agung, Jakarta.

Schermerhorn John, 2008, Managing Organizational Behavior, $2^{\text {nd }}$ edn, John Wiley, Brisbane.

Selfianti, 2013, Pengaruh Gaya Kepemimpinan, Motivasi, Disiplin Kerja dan Kompensasi terhadap Kinerja Pegawai pada Bidang Pendapatan, Bidang Anggaran dan Perbendaharaan DPPKAD Kota Tanjung Pinang, Universitas Merdeka Malang, Malang.

Simamora Henry, 2004,Manajemen Sumber Daya Manusia,edisi Ketiga,STIE YKPN, Yogyakarta.

Stone Raymond J, 2005,Human Resources Management, Fifth Edition, Willey, Australia.

Sudjana, 2000, Statistika untuk Ekonomi dan Niaga, Tarsito, Bandung.

Sutarto, 1998, Dasar-dasar Kepemimpinan Administrasi, Gadjah Mada University Press, Yogyakarta.

Suwatno, 2011,Manajemen Sumber Daya Manusia Dalam Organisasi Publik dan Bisnis,Alfabeta, Bandung.

Thoha Miftah, 2012, Kepemimpinan dalam Manajemen, Rajawali Pers, Jakarta. 
Wahjosumidjo, 1987, Kepemimpinan dan Motivasi, Ghalia Indonesia, Jakarta.

Wahyudi Bambang, 1991, Manajemen Sumber Daya Manusia, CV. Sulita, Bandung.

Wijaya Andre, 2008, Pengaruh Motivasi Kerja, Kepuasan Kerja dan Gaya Kepemimpinan terhadap Kinerja Pegawai pada PT. Nina Album Semarang, Universitas Diponegoro, Semarang. 